\title{
Andersonville Revisited
}

\author{
By Gerald Pratley
}

Spring 1996 Issue of KINEMA

JOHN FRANKENHEIMER'S LATERST FILM, ANDERSONVILLE, opened recently in the USA on the Turner Television Network to excellent reviews and a highly favourable audience response. His 31st motion picture, it takes place during the American Civil War and depicts for the first time on film the terrible suffering of Northern soldiers imprisoned in an overcrowded poorly managed camp run by the army of the South. An atrocity from the past, it also speaks graphically of the barbarities of the present war in Bosnia-Herzegovina and gives terrible meaning once again to the memories of the Holocaust. Implicit in Frankenheimer's treatment and graphic images of man's ever-present brutality towards mankind is the awareness of the powerful forces controlling the lives of certain individuals motivated by power and greed -a theme underlining much of his work and informing the actions of so many of his characters.

\section{Andersonville}

In 1864, more than 32,000 Union Soldiers were imprisoned in Andersonville, a stockade built for 8,000.Almost 13,000 died and are buried there.

Captain Wirz was put on trial after the war and was hanged; the only person to be executed after the Civil War for war crimes.

Frankenheimer: "There is no doubt that my last three films, Against the Wall, The Burning Season and Andersonville, with the extraordinary press they have received, and with the enthusiasm that Turner had for Andersonville, have been instrumental in putting me back in the forefront where I want to be. They have also been very important in terms of my own self-confidence as an artist, as a director. They have made me love what I do again after the quite frankly despairing times I had making Year of the Gun, The Fourth War and before that Dead Bang with nothing but problems with Don Johnson, although I think the film came off in spite him. These three following films have been inspirational for me because it's been highly creative work with fine people both in front of and behind the camera. It's really made a tremendous difference in how I feel -- at this point my life seems very clear and concentrated. I want to keep on doing work like this, with a core group of people with whom I enjoy working and in whom I believe in and who believe in me. The future as we sit here looks relatively good.

Yes, I hear it said that Frankenheimer has 'gone back' to television and I say: No I have not 'gone back' to television. When I was in television I was doing live programs, now I'm making films which are going to be shown on television, made in the same way as though they were going to be shown in cinemas. It's simply a different means of distribution and exhibition. I've already spoken about the bad luck I had with companies who failed to market properly the films I made for them. Now I'm making films knowing they are going to have an immediate audience. In England for instance, directors go between television, features, the stage, opera, commercials, with ease and accomplishment. They just do it.

In America it seems you must be departmentalised -- he's a feature director, a television director, a theatre director, a music director, that's wrong. I think of myself simply as a director and it doesn't really make any difference to me where my films are shown as long as they are shown well, in such a way that people know they are out there; and that the companies who produced them support them and spend some money marketing them. I think that cable, the medium I have been working in for these last three movies -- although there is a chance that Andersonville will go theatrical -- is now what live television was back in the fifties. Then not everyone had a television set so there was a rather elite audience looking at our programs.

Today there is a more selective audience, and we can deal with more demanding and controversial subject matter on cable than in feature films made under the major studio system. I'm not saying that the studio system is wrong or anything like that, but it is easier to do a strong dramatic film on cable today because there is an audience for it, budgets are less, and the risk is not as great. That doesn't mean to say that I wouldn't love to go and do an important feature, which, incidentally, as we speak I think I am about to do, but for my present work there is this additional audience, which is very important for filmmakers like myself. 
Certainly, I went into this film for Turner knowing it would be interrupted by commercials, unlike the two I did for HBO, so I would be hypocritical to tell you that it troubles me. It's not as if they have just sprung the news on me.

There is a chance that it will be shown in cinemas in which case of course, there will be no commercials. I have not structured the screenplay or built the film to accommodate commercials, but there are natural act-breaks in the narrative and I think the movie is strong enough to hold through the commercials. This is a very expensive movie; the budget was in excess of 17 or 18 million dollars and it's very courageous of the Turner people to finance it. I don't know of anybody else who would. I can't see anyone else putting up this kind of money for this subject matter and I hope that it justifies their investment -- I think it will. Looking at the movie you will see exactly where the money went to. There are thousands of people on the screen, the set itself is nine acres in diameter plus four acres outside. It's an epic production and the fact that we were able to do it for this amount of money is a miracle. Every day there have been over a thousand extras, we shot for over 60 days. It's a terribly difficult undertaking, there is no such thing as a simple shot on this movie, it's among the most difficult movies I've ever done. Had it been made for Paramount or Universal it would probably have cost twice as much or more.

Yet I don't think we've compromised this film at all. There's really very little I would have done differently. I don't want to be critical of the major studios, Gerald, that's not what I'm in the business of doing. The budget would have been much higher above the line for the actors, for me, for the writer. Using stars in the public sense of the word, would have cost more. I don't think this movie will look compromised at all either on a small or a big screen. I think it will go theatrical without any of us thinking: If we'd meant to do it this way we would have spent more money. Because I don't think we would have. If I hadn't done the other two movies I might never have done this in the first place, because I would have said: It's impossible to shoot it in 60 days.

But again, because of an extraordinary crew and actors, we have succeeded. Theoretically however, there is not a major studio around that would have sunk even 30 million dollars into this subject matter. It would be foolish. If a major studio had made this movie the budget should have been no more than we made it on, otherwise they wouldn't have made it, it's that simple. I mean the individuals running the major studios are not fools. They have a good idea of what their audience wants and what is going to succeed, and I don't think they would say: "Well, great, we're going to spend 30 million dollars on Andersonville, this picture about a prison camp." I really commend Ted Turner for saying: "This is what I want to do." And he has not asked me to compromise in any way. I think Turner is one of the bravest figures around in this business today, and I just hope that I've made a movie that will justify his faith in me. And no, it's not "another action movie" as some critics have said. I don't think I've ever done an action picture except for The Train and Grand Prix. You night call them action pictures, but they are the only two; but like my other films, they are also dramas."

\section{Notes}

(From the book The Films of Frankenheimer by Gerald Pratley published by Associated University Presses of Cranbury, NJ, USA.)

\section{Author Information}

Gerald PRATLEY, OC, LLD, started his career as film critic with the CBC. In 1969, he founded the Ontario Film Institute which he directed until 1990. He has written several books and numerous articles on film, including Torn Sprockets, a history of Canadian cinema. He taught Film History in universities in Toronto and Waterloo, Canada and holds three honorary degrees from Canadian and US universities.

Gerald A. Pratley (1923-2011) was born and educated in London, England, and came to Canada in 1946. He started working in Toronto for the $\mathrm{CBC}$ as a scriptwriter. He was drawn toward working in motion pictures, and became, in 1948, the CBC's first film critic and commentator. 
Gerald Pratley broadcast three programmes a week, Pratley at the Movies, The Movie Scene, Music From the Films, and others, until 1975. During this time he also became the first post-war chairman of the Toronto Film Society, chairman of the Toronto and District Film Council and co-founder of the A-G-E Film Society and correspondent for international magazines such as Films and Filming, Film In Review, Variety, Hollywood Quarterly and International Film Guide. During the 1950s he wrote for Canadian Film Weekly and Canadian Film Digest.

He became known as a speaker on all aspects of motion picture art and industry, and was invited to teach film history at the University of Toronto, York University, University of Waterloo, Seneca College and Ryerson Polytechnical University, with individual lectures being given at many other Canadian and US universities and colleges. He has served as a member of various judging panels of competitions and festivals, being one of the members of the first Canadian Film Awards in 1949.

From 1970 to 1975 he was the director of the Stratford (Ontario) International Film Festival, and from 1969 to 1976 he was Chairman of the International Jury of the Canadian Film Awards. He has attended all the world's leading festivals of film, and in particular, for 30 years, the Cannes Festival as CBC correspondent. He has written six books, The Films of Frankenheimer: Forty Years in Film; The Cinema of John Frankenheimer; The Cinema of Otto Preminger; The Cinema of David Lean; The Cinema of John Huston, and Torn Sprockets, a history of the Canadian cinema.

Gerald Pratley has served on the Advisory Boards of the film departments of Ryerson Polytechnical University and Humber College, and as a member of the programme committee of TV Ontario. In 1968 he became the founder-director of the Ontario Film Institute of the Province of Ontario, an organization which has distinguished itself in archival holdings and public service and is known since 1990 as the Cinematheque of Ontario. He taught Film History courses at the Department of Film and Photography, Ryerson Polytechnic University, Toronto and the University of Waterloo.

In 1984, Gerald Pratley was made a Member of the Order of Canada and in 2003 Officer of the Order of Canada for his service to Canada through film appreciation. He holds Honorary Degrees in Letters and Fine Arts from York and Waterloo Universities (Ont., Canada) and Bowling Green State University (Ohio, USA).

In 2002, Gerald Pratley received a Special Genie Award from the Academy of Canadian Cinema \& Television in recognition of his lifelong dedication to the promotion and his exceptional support of Canadian cinema.

He died on 14 March 2011 in Ontario, Canada. 